University of Nebraska - Lincoln

DigitalCommons@University of Nebraska - Lincoln

1996

\title{
Origin of Bermuda's clay-rich Quaternary paleosols and their paleoclimatic significance
}

Stanley R. Herwitz

Clark University

Daniel R. Muhs

U.S. Geological Survey, dmuhs@usgs.gov

Joseph M. Prospero

University of Miami

Shannon Mahan

U.S. Geological Survey

Bruce Vaughn

U.S. Geological Survey

Follow this and additional works at: https://digitalcommons.unl.edu/usgsstaffpub

Part of the Earth Sciences Commons

Herwitz, Stanley R.; Muhs, Daniel R.; Prospero, Joseph M.; Mahan, Shannon; and Vaughn, Bruce, "Origin of Bermuda's clay-rich Quaternary paleosols and their paleoclimatic significance" (1996). USGS Staff -Published Research. 165.

https://digitalcommons.unl.edu/usgsstaffpub/165

This Article is brought to you for free and open access by the US Geological Survey at DigitalCommons@University of Nebraska - Lincoln. It has been accepted for inclusion in USGS Staff -- Published Research by an authorized administrator of DigitalCommons@University of Nebraska - Lincoln. 


\title{
Origin of Bermuda's clay-rich Quaternary paleosols and their paleoclimatic significance
}

\author{
Stanley R. Herwitz, ${ }^{1}$ Daniel R. Muhs, ${ }^{2}$ Joseph M. Prospero, ${ }^{3}$ Shannon Mahan, ${ }^{2}$ \\ and Bruce Vaughn ${ }^{2}$
}

\begin{abstract}
Red clayey paleosols that are chiefly the product of aerosolic dust deposition are interbedded in the Quaternary carbonate formations of the Bermuda oceanic island system. These paleosols provide a basis for reconstructing Quaternary atmospheric circulation patterns in the northwestern Atlantic. Geochemical analyses were performed on representative paleosol samples to identify their parent dust source. Fine-grained fractions were analyzed by energy-dispersive $X$ ray fluorescence to determine trace element $(\mathrm{Zr}, \mathrm{Y}, \mathrm{La}, \mathrm{Ti}$, and $\mathrm{Nb}$ ) concentrations and to derive geochemical signatures based on immobile element ratios. These ratios were compared with geochemical signatures determined for three possible sources of airborne dust: (1) Great Plains loess, (2) Mississippi River Valley loess, and (3) Saharan dust. The $\mathrm{Zr} / \mathrm{Y}$ and $\mathrm{Zr} / \mathrm{La}$ ratios provided the clearest distinction between the hypothesized dust sources. The low ratios in the paleosol B horizons most closely resemble Saharan dust in the $<2-\mu \mathrm{m}$ size class fraction. Contributions from the two North American loessial source areas could not be clearly detected. Thus Bermuda paleosols have a predominantly Saharan aerosolic dust signature. Saharan dust deposition on Bermuda during successive Quaternary glacial periods is consistent with patterns of general circulation models, which indicate that during glacial maxima the northeast summer trade winds were stronger than at present and reached latitudes higher than $30^{\circ} \mathrm{N}$ despite lower-than-present sea surface temperatures in the North Atlantic.
\end{abstract}

\section{Introduction}

The usefulness of reconstructing atmospheric circulation during the glacial-interglacial cycles of the last 2 m.y. has become increasingly important due to growing concerns about global climate change. General circulation modeling of the northern hemisphere suggests that the northeast summer trade winds between $24^{\circ}$ and $36^{\circ} \mathrm{N}$ latitude were stronger during Quaternary glacial periods than at present [Kutzbach, 1987]. Palynological analyses of northwest African marine sediments are consistent with this interpretation [Hooghiemstra et al., 1987; Hooghiemstra, 1988]. Keffer et al. [1988], on the other hand, concluded that the reduction in North Atlantic sea surface temperatures during glacial maxima caused a significant southward summer shift in the Gulf Stream-North Atlantic Current system and the subtropical-subpolar frontal system. The geological record of Bermuda, located at $32^{\circ} \mathrm{N}$ latitude in the northwest Atlantic, provides a unique opportunity for addressing these contrasting views of Quaternary paleocirculation.

The oceanic island system of Bermuda currently exposed above sea level is a lithified dune field composed of calcareous eolianites. The eolianites are Quaternary in age and are locally

\footnotetext{
${ }^{1}$ Departments of Geography and Biology, Clark University, Worcester, Massachusetts.

${ }^{2}$ U.S. Geological Survey, Denver, Colorado.

${ }^{3}$ Rosenstiel School of Marine and Atmospheric Sciences, University of Miami, Miami, Florida.

Copyright 1996 by the American Geophysical Union.

Paper number 96JD02333.

0148-0227/96/96JD-02333\$09.00
}

derived from biogenic beach sediments that constitute $>90 \%$ of the total rock volume above sea level [Land et al., 1967; Vacher, 1973; Harmon et al., 1981; Vacher and Hearty, 1989]. These eolianites overlie a submerged volcanic seamount. Interbedded between the eolianites and some minor marine carbonates are clay-rich "terra rossa" paleosols [Ruhe et al., 1961; Rowe, 1990; Hearty and Vacher, 1994; Herwitz and Muhs, 1995]. Paleosols interbedded between datable rocks provide valuable opportunities for reconstructing past conditions over definable time periods.

The Bermuda paleosols are reddish to reddish brown in color and consist of high concentrations of aluminosilicate clays [Ruhe et al., 1961; Vacher and Hearty, 1989]. Reddish brown, clayey soils that formed by different processes have been studied in many parts of the world [Pye, 1983]. In situ weathering of calcareous rock formations has been suggested as a possible pedogenic mechanism in other areas [Prasad, 1983; Moresi and Mongelli, 1988; Pye, 1992]. Bermuda's highpurity eolianites contain insufficient $\mathrm{Si}$ - and $\mathrm{Al}$-bearing minerals to generate reddish brown, clay-rich soil over periods of $<10^{5}$ years [Herwitz and Muhs, 1995]. The mineralogy and geochemistry of Bermuda's paleosols indicate that the paleosols are not the insoluble residue of weathered eolianite. The generally accepted view is that most of the red clay fraction of Bermudan paleosols represents accumulations of finegrained airborne dust originating from distant continental source areas [Bricker and Prospero, 1969; Bricker and Mackenzie, 1970; Herwitz and Muhs, 1995].

Determination of the source of Bermuda's paleosols would provide a basis for testing models of Quaternary atmospheric circulation patterns in the North Atlantic. Given the long residence time of atmospheric dust and the great distances it can 
travel [Rahn et al., 1979], any stable subaerial surface is a potential site of deposition. Long-term accumulations at a given site may therefore represent a mix of dust from widely separated source areas. The objective of our study was to identify the predominant source area(s) that contributed to these accumulations on Bermuda. Immobile trace elements that do not experience differential chemical weathering, release, and removal have been used as a basis for geochemical fingerprinting because they maintain the same relative proportions over time [Muhs et al., 1990]. We identified the geochemical signatures of Bermudan paleosols and related them to the signatures of aerosolic dust from likely continental sources using immobile element ratios. These data provided a basis for evaluating models of Quaternary atmospheric circulation patterns in the northwestern Atlantic.

\section{Quaternary History of Bermuda}

The calcareous dunes that lithified to eolianite were first thought to have formed during glacial low sea stands when the Bermuda platform was more exposed, whereas the paleosols formed during interglacials [Sayles, 1931; Livingston, 1944; Officer et al., 1952]. This interpretation was challenged by Bretz [1960], who argued that the dunes developed during interglacial high sea stands and the clay-rich soils formed during glacial maxima. Submerged eolianite units, however, have been reported on the Bermuda platform at depths ranging from 18 to $75 \mathrm{~m}$ below present-day sea level [Pirsson, 1914; Stanley and Swift, 1967]. These submerged eolianites and other stratigraphic evidence indicate that the large lithified dune ridges that constitute the bulk of the island system did not form during high or low sea stands but rather formed rapidly during the first phases of sea level regressions at the end of interglacials [Vacher and Hearty, 1989]. The succession of onlapping and locally overlapping eolianites reflects progradation of younger dune units over older units [Vacher, 1973; Vacher et al., 1995].

Six eolianite formations ranging in age from $>880$ to $85 \mathrm{ka}$ have been distinguished on the basis of stratigraphic position, relative degree of lithification, uranium series dating of speleothems and fossil coral samples, and amino acid racemization dating of eolianite, fossil land snail, and fossil marine mollusk samples [Harmon et al., 1983; Vacher and Hearty, 1989; Vacher et al., 1989; Hearty et al., 1992]. From oldest to youngest, these eolianites are (1) the Walsingham Formation $\left(\mathrm{Q}_{w},>880\right.$ $k a),(2)$ the Lower Town Hill Formation $\left(Q_{t l}, 430-475 \mathrm{ka}\right),(3)$ the Upper Town Hill Formation $\left(Q_{t u}, 325-350 \mathrm{ka}\right)$, (4) the Belmont Formation $\left(Q_{b}, 200-225 \mathrm{ka}\right),(5)$ the Rocky Bay Formation $\left(Q_{r}, \sim 125 \mathrm{ka}\right)$, and (6) the Southampton Formation $\left(Q_{s}, \sim 85 \mathrm{ka}\right)$ [Vacher et al., 1995]. The ages of the Southampton, Rocky Bay, and Belmont Formations are based on uranium series dating of speleothems and corals from the beach or marine facies [Harmon et al., 1983]. Age estimates of the older units are based on amino acid ratios of whole-rock eolianite samples and amino acid ratios of land snails from the eolianites, calibrated by the uranium-series-dated units [Hearty et al., 1992]. Given these ages of Bermuda's eolianite formations, the interbedded paleosols were subaerially exposed and formed over time periods ranging from $\sim 40,000$ to $>400,000$ years. Those soils that formed over the longer time periods represent composite units.

\section{Materials and Methods \\ Paleosol Collection}

Red clay soils are distributed throughout Bermuda. Plate 1a shows a subaerially exposed red clay soil surface representing their presumed condition before burial by calcareous eolian deposits. We studied red clay paleosols overlain by carbonates (Plate 1b) at sites delineated on Vacher et al.'s [1989] geological map of Bermuda. Soil samples (100-300 g) were collected at sites where the different eolianite formations were represented (Figure 1). Most of the sample sites were exposed at road or railway cuts or in the walls of abandoned quarries (Plate 2). The number of samples collected at each site depended on soil thickness and the number of horizons; commonly, two to seven samples were collected at each site.

All samples were from paleosol profiles with $\mathrm{A}$ and $\mathrm{B}$ horizons (Plate 3a), and, in some cases, distinguishable subhorizons (e.g., Bt1; Bt2). Paleosols that did not appear to have B horizons were not selected (Plate $3 b$ ) because of their high carbonate content $(>50 \%)$ and their relatively low proportions of red clay. Trace element concentrations in soil A horizons were so low that they could not be used for a meaningful definition of a geochemical signature. Signatures described in this paper are mainly limited to samples collected from B horizons. In preliminary studies of Bermuda paleosols, our analyses were limited to samples collected from the interiors of soil-filled solution pipes [Herwitz, 1993; Herwitz and Muhs, 1995]. Paleosol samples collected from the interiors of solution pipes at Whalebone Bay (Figure 1) were included in this study because of their close proximity to Whalebone Bay's Upper Town Hill marine facies $\left(Q_{t m}\right)$, which contains the most concentrated occurrence of volcanic detritus on Bermuda. Of particular interest was how these volcanic constituents may have affected the geochemical signatures of Bermuda's paleosols.

\section{Geochemical Analyses of Paleosols and Eolian Sources}

The fine-grained fractions of 38 paleosol samples from the 15 localities shown in Figure 1 (including Whalebone Bay) were analyzed by energy-dispersive $\mathrm{X}$ ray fluorescence [Johnson and King, 1987]. Each sample was passed through a 2-mm sieve, crushed to $<200$ mesh, and homogenized prior to analysis. The powdered samples were analyzed for concentrations of the immobile trace elements $\mathrm{Zr}, \mathrm{Y}, \mathrm{La}, \mathrm{Ti}$, and $\mathrm{Nb}$. Mean immobile element ratios were computed for the five paleosol units positioned between the eolianite formations $Q_{t u} / Q_{t}$ and $Q_{w}, Q_{b}$ and $Q_{t u}, Q_{r}$ and $Q_{t u}, Q_{r}$ and $Q_{b}$, and $Q_{s}$ and $Q_{r}$, where $Q_{w}$ is Walsingham, $Q_{t l}$ is Lower Town Hill, $Q_{t u}$ is Upper Town Hill, $Q_{b}$ is Belmont, $Q_{r}$ is Rocky Bay, and $Q_{s}$ is Southampton.

The geochemical signatures defined by the elemental ratios were compared with the signatures of airborne dust from likely source areas. This approach is similar to that used by Muhs et al. [1990] in their study of soils on Quaternary carbonates of the Caribbean islands, which revealed that Saharan dust was the dominant parent material. Bricker and Prospero [1969] were the first to suggest that Bermuda's paleosols represent accumulations of aerosolic dust originating from northwest Africa. Other possible aerosolic dust sources are North American loess deposits in the Great Plains [Holliday, 1991] and the lower Mississippi River Valley [Fisk, 1951; Pye and Johnson, 1988]. These North American sources should have geochemical signatures distinct from those of northwest Africa because of differences in parent material mineralogy and in trace ele- 

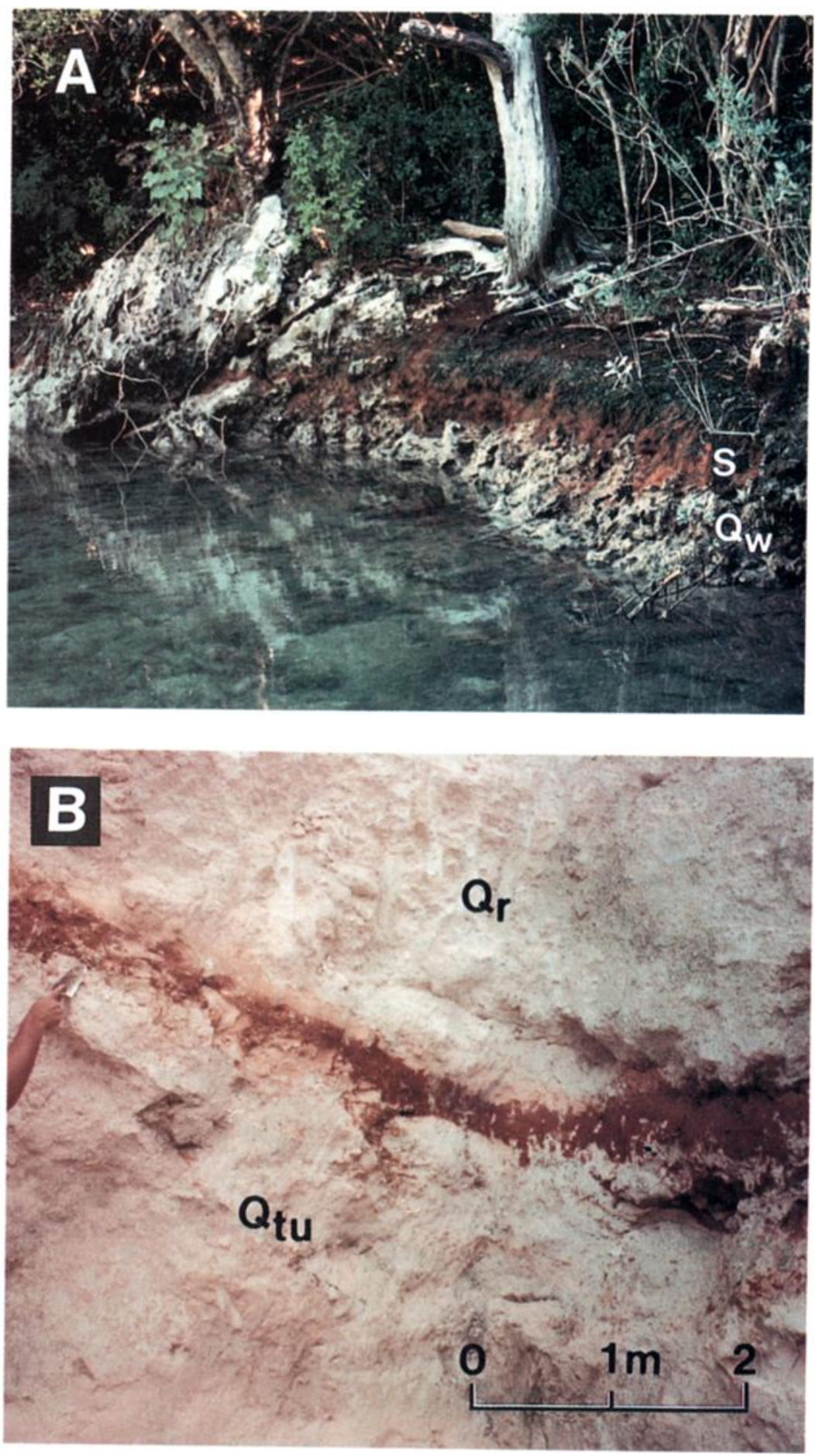

Plate 1. Clay-rich red soils of Bermuda: (a) subaerially exposed (S) and underlain by the Walsingham Formation $\left(Q_{w}\right)$ adjacent to a sinkhole in the Idwal Hughes Nature Reserve, and (b) underlain by the Upper Town Hill Formation $\left(Q_{t u}\right)$ and overlain by the Rocky Bay Formation $\left(Q_{r}\right)$ exposed in fresh cut at a construction site on Gibbon Road near North Shore Road southwest of Bailey's Bay.

ment compositions in the same minerals [Herwitz and Muhs, 1995].

Because the fine-grained fraction of North American loesses has the highest probability of reaching the western Atlantic Ocean during dust storms [Windom and Chamberlain, 1978; McCauley et al., 1981], we isolated the fine-grained $(<10 \mu \mathrm{m})$ fractions from whole-sediment samples collected from representative localities. Mississippi River Valley loess samples were collected from 8 sample sites in Mississippi, 11 in Louisiana, 7 in Arkansas, and 1 in Tennessee. Great Plains loess samples were from 9 sites in eastern Colorado and from 13 sites in the area of eastern New Mexico and western Texas.

The geochemical signatures of Saharan dust were based on bulk filter samples of Saharan dust collected from Sal Island (the northeasternmost island in the Cape Verde archipelago), Barbados, and Miami, Florida (Figure 1) by J. Prospero and 


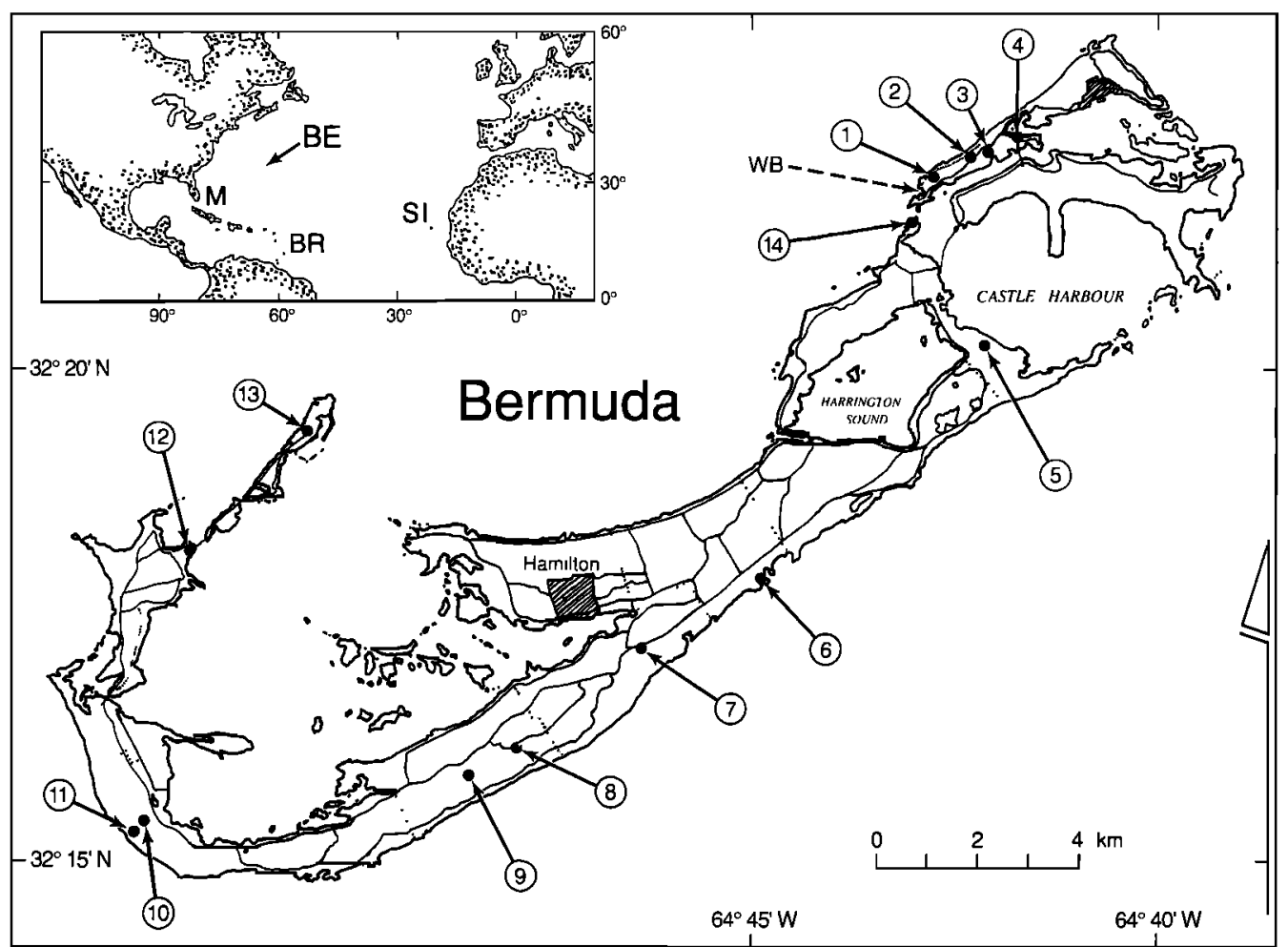

Figure 1. Location of Bermuda (BE), Barbados (BR), and Miami (M) in the western Atlantic and Sal Island (SI) in the eastern Atlantic (inset) and of Bermuda's Whalebone Bay (WB) and paleosol sample sites 1-14. Samples were taken between the following eolianite formations: $1, Q_{r}$ (Rocky Bay) and $Q_{t u}$ (Upper Town Hill) along Railway Trail, St. George's Island; $2, Q_{r}$ and $Q_{t u}$ on Pendle Hill, St. George's Island; 3, $Q_{t u}$ and $Q_{w}$ (Walsingham) at Shore Hills site on Esso fuel storage property, St. George's Island; 4, $Q_{4}$ (Southampton) and $\mathrm{Q}_{\mathrm{r}}$ at intersection of Swing Bridge and Ferry Reach Roads, St. George's Island; 5, $\mathrm{Q}_{\mathrm{tl}}$ (Lower Town Hill) and $\mathrm{Q}_{\mathrm{w}}$ at entrance to Castle Harbour Marriott Hotel; 6, $\mathrm{Q}_{\mathrm{r}}$ and $\mathrm{Q}_{\mathrm{b}}$ (Belmont) on Rocky Bay Hill; 7, $\mathrm{Q}_{\mathrm{b}}$ and $\mathrm{Q}_{\mathrm{tu}}$ along Railway Trail at entrance to Grape Bay Road adjacent to South Road; $8, \mathrm{Q}_{\mathrm{b}}$ and $\mathrm{Q}_{\mathrm{tu}}$ on Ord Road adjacent to Cobb Hill Road intersection; $9, Q_{r}$ and $Q_{b}$ on Spice Hill Road; 10, $Q_{r}$ and $Q_{t u}$ adjacent to Mount Zion Church; 11, $Q_{r}$ and $Q_{t u}$ on Whale Bay Road in Southampton; 12, $Q_{s}$ and $Q_{r}$ on Somerset Island; 13, $Q_{t l}$ and $\mathrm{Q}_{\mathrm{w}}$ on Ireland Island North; and $14, \mathrm{Q}_{\mathrm{r}}$ and $\mathrm{Q}_{\mathrm{b}}$ on Coney Island.

analyzed using emission spectroscopy. To evaluate possible differences in the geochemical signatures as a function of particle size, nylon mesh samples of Saharan dust collected by Prospero on Barbados were fractionated into four particle size classes $(10-20 \mu \mathrm{m}, 5-10 \mu \mathrm{m}, 2-5 \mu \mathrm{m}$, and $<2 \mu \mathrm{m})$ and analyzed using instrumental neutron activation. The procedures used for protecting the samples from local contamination are described by Delany et al. [1967] and Prospero [1968].

Immobile element ratios from the different sample sites were determined, and the range and weighted mean values were computed for each of the three possible sources: (1) Mississippi River Valley loess (hereinafter referred to as Mississippi loess), (2) Great Plains loess, and (3) Saharan dust.

\section{Results}

\section{Eolian Source and Paleosol Geochemical Signatures}

Of all the ratios examined, the $\mathrm{Zr} / \mathrm{Y}$ ratio provides one of the clearest distinctions between the three hypothesized dust sources, with Great Plains loess having the highest values (mean \pm 1 s.d. $=9.44 \pm 1.42$ ) and Saharan dust having the lowest (4.26 \pm 0.80$)$. Mississippi loess has intermediate values $(7.04 \pm 1.26)$ that overlap slightly with those of Great Plains loess (Figure 2). The $\mathrm{Zr} / \mathrm{Y}$ ratios of most of the Bermuda paleosols (Table 1) are lower than the ratios of all three hypothesized source areas. Bermuda paleosols interbedded between the relatively young Southampton and Rocky Bay Formations have $\mathrm{Zr} / \mathrm{Y}$ ratios that are suggestive of a Saharan dust source (Figure 2). One outlier is the paleosol between the Rocky Bay and Belmont Formations at site 14 on Coney Island (Figure 1 and Plate 2b), which has $\mathrm{Zr} / \mathrm{Y}$ ratios consistent with a Mississippi loess source; however, closer examination of the site 14 samples using light microscopy revealed that the soil profile at this site may be more accurately characterized as a protosol.

Of the three hypothesized sources, the $\mathrm{Zr} / \mathrm{Y}$ ratios in Saharan dust (Table 2) are closest to those of Bermuda's paleosols. Nevertheless, the mean $\mathrm{Zr} / \mathrm{Y}$ values for all five paleosol groups shown in Figure 2 are lower than those for Saharan dust, suggesting either (1) a different parent material or (2) lower $\mathrm{Zr} / \mathrm{Y}$ values in Saharan dust reaching Bermuda as compared with Saharan dust reaching Sal Island, Barbados, and Miami. We favor the latter hypothesis because the atmospheric circulation path from northwest Africa to Bermuda may be several hundred kilometers greater and the aerosolic dust may not be maintaining a stable size distribution. Zirconium, which is found almost exclusively in the heavy mineral zircon, is likely to be depleted more than Y. Zircon is known to 


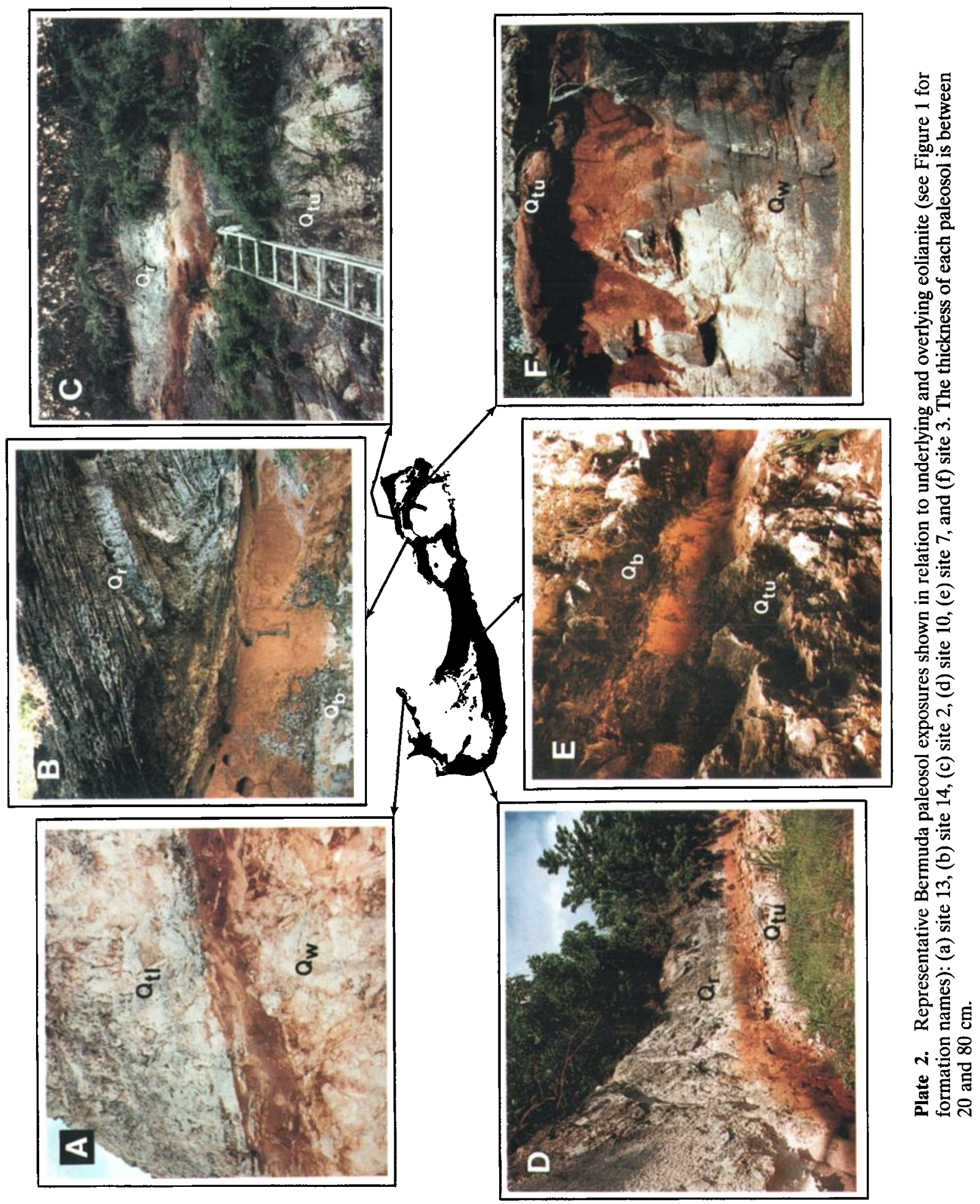



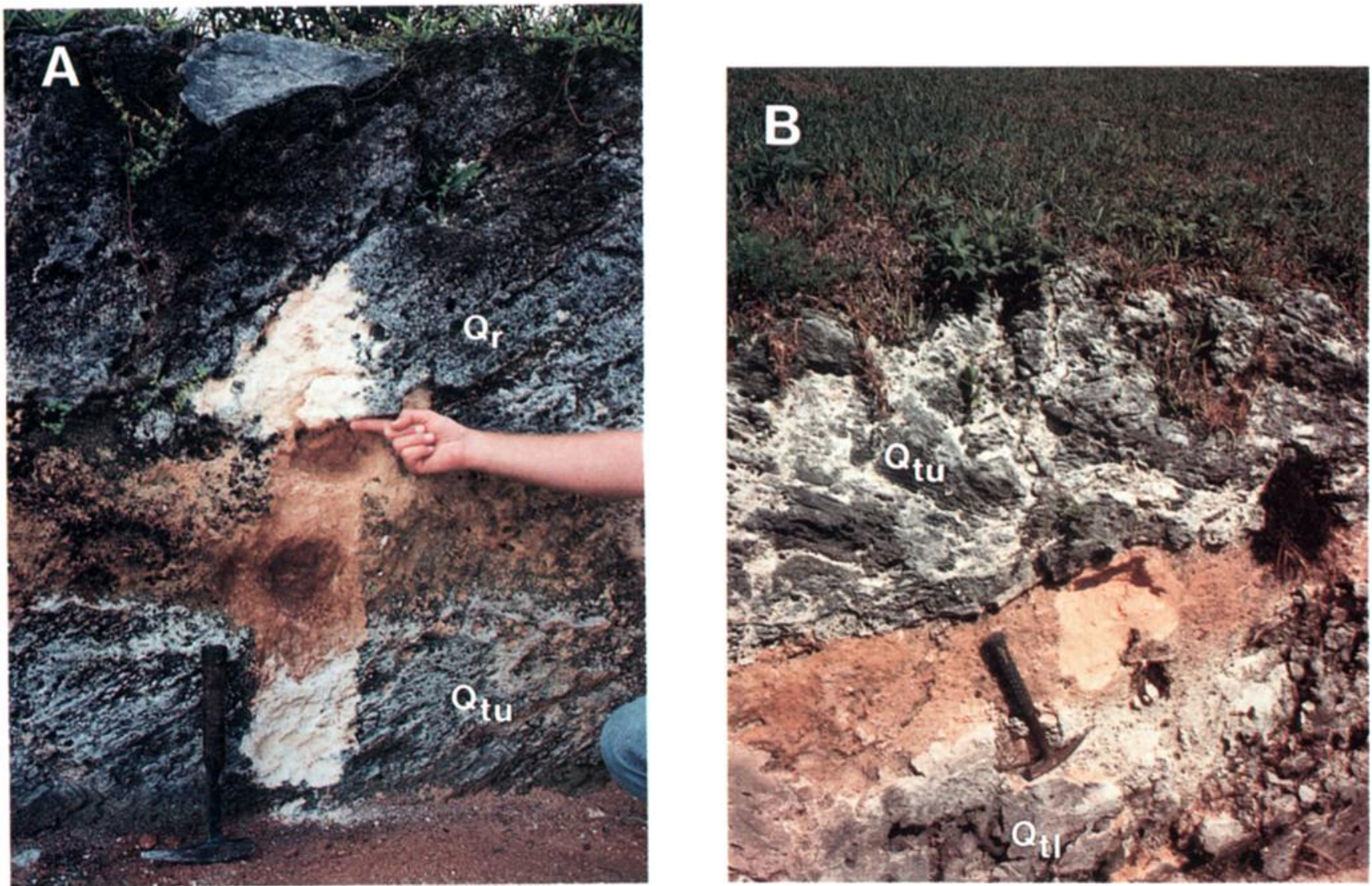

Plate 3. Close-up views of Bermuda paleosol profiles illustrating (a) a well-developed paleosol with $\mathrm{A}$ and B horizons at site 10 (Plate 2d) and (b) a protosol along Paynter's Road approximately $0.5 \mathrm{~km}$ southwest of site 5 .

concentrate preferentially in the coarser silt fraction of particles derived from rock weathering [Chapman and Horn, 1968]. Size fractionation thus may be greater for $\mathrm{Zr}$ than for $\mathrm{Y}$. On the basis of the data set forth in Table 2 , the mean $\mathrm{Zr} / \mathrm{Y}$ ratio of 4.5 at Sal Island decreases to a value of 4.1 at Barbados. Although this decrease is not pronounced, it raises the possibility of further size fractionation as the dust continues on a longer travel route to Bermuda.

The $\mathrm{Zr} / \mathrm{La}$ ratios differ from the $\mathrm{Zr} / \mathrm{Y}$ ratios in that the Mississippi and Great Plains loesses are not as readily distinguished from each other. However, the Saharan dust signature remains distinct, with a lower mean value ( \pm 1 s.d.) of $2.63 \pm$ 0.50 . The $\mathrm{Zr} / \mathrm{La}$ ratios of Bermuda paleosols are most concentrated in this range (Figure 3). Most of the paleosol $\mathrm{Zr} / \mathrm{La}$ ratios are statistically indistinguishable from Saharan dust. Exceptions are the younger paleosols between the Rocky Bay and Southampton Formations, which have values more consistent with those of the Mississippi loess signature, and the anomalous site 14 outlier that has a mean $\mathrm{Zr} / \mathrm{La}$ value exceeding those of all three source areas. Although there is some overlap with Mississippi loess, most of the paleosol $\mathrm{Zr} / \mathrm{La}$ ratios are strongly suggestive of a Saharan dust source.

The complicating issue is why the $\mathrm{Zr} / \mathrm{La}$ ratios are more consistent with Saharan dust than the $\mathrm{Zr} / \mathrm{Y}$ ratios. One possible explanation is variability in the immobile element ratios as a function of particle size. How representative are analyses

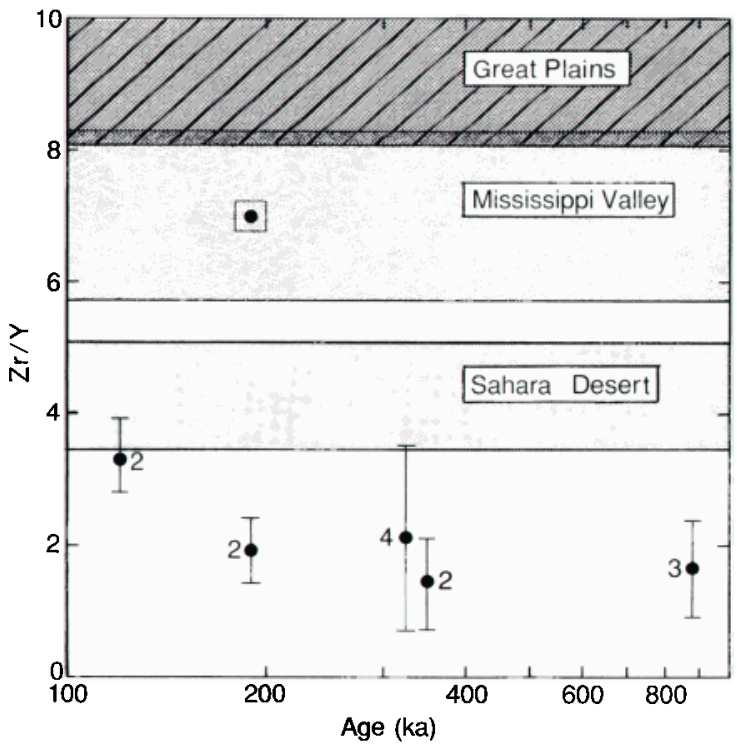

Figure 2. Mean $\mathrm{Zr} / \mathrm{Y}$ ratios ( \pm 1 s.d.) from paleosol sample sites as a function of age of underlying eolianite shown in relation to the range of values (mean \pm 1 s.d.) of the three possible sources areas: Great Plains, Mississippi Valley, and Sahara Desert. The numbers next to each mean value show the number of paleosol sample sites represented. The boxed-in outlier represents the $\mathrm{Zr} / \mathrm{Y}$ ratio from site 14 . 
involving the entire $<10-\mu \mathrm{m}$ particle size fraction for characterizing the aerosols that reached Bermuda? This question was addressed by the neutron activation determinations of $\mathrm{Zr} / \mathrm{La}$ values for Saharan dust samples subdivided into the four particle size class groupings of $10-20 \mu \mathrm{m}, 5-10 \mu \mathrm{m}, 2-5 \mu \mathrm{m}$, and $<2 \mu \mathrm{m}$ (Table 3). The result is a decline in the $\mathrm{Zr} / \mathrm{La}$ ratio as a function of decreasing particle size (Figure 4). The mean $\mathrm{Zr} / \mathrm{La}$ ratio is 6.35 for the 5- to $10-\mu \mathrm{m}$ size class and only 2.87 for the $<2-\mu \mathrm{m}$ size class. This decrease is attributable to the marked decrease in the $\mathrm{Zr}$ concentrations in Saharan dust with decreasing particle size. In contrast, the La concentrations increased only slightly with decreasing particle size. The low $\mathrm{Zr} / \mathrm{Y}$ ratios of the Bermuda paleosols thus may be attributed to their derivation from a finer fraction of Saharan dust than was previously thought.

The best fit equation shown in Figure 4 can be used to estimate the mean particle size fraction of Saharan dust reaching Bermuda. The mean $\mathrm{Zr} / \mathrm{La}$ ratio of 3.03 for all of the sampled $B$ horizon Bermuda paleosols (excluding the anomalous site 14) suggests a mean dust particle size of $1.9 \mu \mathrm{m}$, which is slightly finer grained than the mean dust particle size reach-

Table 1. Trace Element Concentrations and Ratios of Bermuda Paleosols Determined by Energy-Dispersive X Ray Fluorescence

\begin{tabular}{|c|c|c|c|c|c|c|c|}
\hline \multirow{2}{*}{$\begin{array}{c}\text { Stratigraphic } \\
\text { Unit* }\end{array}$} & \multicolumn{2}{|c|}{ Sample } & \multicolumn{3}{|c|}{ Concentration, ppm } & \multicolumn{2}{|c|}{ Ratio } \\
\hline & Site & No. & $\mathrm{Zr}$ & Y & $\mathrm{La}$ & $\mathrm{Zr} / \mathrm{Y}$ & $\mathrm{Zr} / \mathrm{La}$ \\
\hline \multirow[t]{2}{*}{$Q_{\mathrm{s}} / \mathrm{Q}_{\mathrm{r}}$} & 12 & $\mathrm{sm}-2$ & 96.3 & 26.0 & 28.8 & 3.7 & 3.3 \\
\hline & 4 & $\mathrm{ff}-2$ & 188.8 & 64.1 & 48.4 & 2.9 & 3.9 \\
\hline \multirow{5}{*}{$Q_{r} / Q_{b}$} & 6 & rb-2 & 179.0 & 79.0 & 72.9 & 2.3 & 2.5 \\
\hline & 9 & sh-1 & 61.6 & 94.6 & 20.6 & 0.7 & 3.0 \\
\hline & & sh-2 & 112.4 & 45.1 & 45.6 & 2.5 & 2.4 \\
\hline & 14 & cn-1 & 116.3 & 12.3 & 10.4 & 9.5 & 11.2 \\
\hline & & $\mathrm{cn}-2$ & 123.1 & 27.2 & 25.8 & 4.5 & 4.8 \\
\hline \multirow[t]{16}{*}{$Q_{r} / Q_{1 u}$} & 1 & $\mathrm{rr}-2$ & 131.1 & 26.9 & 25.0 & 4.9 & 5.2 \\
\hline & & $\mathrm{rr}-3$ & 122.4 & 44.2 & 29.4 & 2.8 & 4.2 \\
\hline & 2 & $\mathrm{pr}-2$ & 157.4 & 79.1 & 49.6 & 2.0 & 3.2 \\
\hline & & pr-3 & 213.5 & 173.6 & 117.1 & 1.2 & 1.8 \\
\hline & & $\mathrm{pr}-4$ & 289.2 & 377.1 & 214.7 & 0.8 & 1.3 \\
\hline & 10 & $\mathrm{zi}-3$ & 282.6 & 400.3 & 161.1 & 0.7 & 1.8 \\
\hline & & zi-4 & 289.6 & 460.4 & 175.1 & 0.6 & 1.7 \\
\hline & & $\mathrm{zi}-5$ & 168.4 & 347.8 & 96.6 & 0.5 & 1.7 \\
\hline & & zi-7 & 296.0 & 311.0 & 164.0 & 1.0 & 1.8 \\
\hline & 11 & $z z-10$ & 111.9 & 41.1 & 17.7 & 2.7 & 6.3 \\
\hline & & $z z-11$ & 87.8 & 48.3 & 28.8 & 1.8 & 3.0 \\
\hline & & $z z-12$ & 122.9 & 43.4 & 29.4 & 2.8 & 4.2 \\
\hline & & $z z-16$ & 97.6 & 27.8 & 21.0 & 3.5 & 4.6 \\
\hline & WB & wb-40 & 265.4 & 152.2 & 554.7 & 1.7 & 0.5 \\
\hline & & wb-42 & 391.0 & 181.7 & 595.0 & 2.2 & 0.7 \\
\hline & & wb-44 & 294.3 & 113.3 & 477.1 & 2.6 & 0.6 \\
\hline \multirow{3}{*}{$\mathrm{Q}_{\mathrm{h}} / \mathrm{Q}_{\mathrm{tu}}$} & 7 & $\mathrm{gr}-1$ & 195.1 & 326.7 & 137.0 & 0.6 & 1.4 \\
\hline & & gr-3 & 211.6 & 163.8 & 99.1 & 1.3 & 2.1 \\
\hline & 8 & or-1 & 130.4 & 68.8 & 35.7 & 1.9 & 3.7 \\
\hline \multirow[t]{3}{*}{$\mathrm{Q}_{\mathrm{tu}} / \mathrm{Q}_{\mathrm{w}}$} & 3 & es-20 & 875.0 & 386.1 & 248.8 & 2.3 & 3.5 \\
\hline & & es-21 & 875.5 & 376.5 & 256.8 & 2.3 & 3.4 \\
\hline & & es-22 & 889.4 & 352.9 & 331.8 & 2.5 & 2.7 \\
\hline \multirow[t]{9}{*}{$\mathrm{Q}_{\mathrm{t}} / \mathrm{Q}_{\mathrm{w}}$} & 5 & $\mathrm{mh}-1$ & 334.1 & 257.3 & 121.0 & 1.3 & 2.8 \\
\hline & & mh-3 & 122.4 & 103.9 & 46.2 & 1.2 & 2.6 \\
\hline & & mh-5 & 222.2 & 200.3 & 103.4 & 1.1 & 2.1 \\
\hline & & mh-6 & 360.5 & 631.8 & 225.3 & 0.6 & 1.6 \\
\hline & & $\mathrm{mh}-7$ & 272.5 & 684.4 & 214.9 & 0.4 & 1.3 \\
\hline & & mh-8 & 360.6 & 310.4 & 150.3 & 1.2 & 2.4 \\
\hline & & mh-9 & 158.2 & 367.0 & 133.9 & 0.4 & 1.2 \\
\hline & & $\mathrm{mh}-10$ & 359.0 & 416.8 & 197.0 & 0.9 & 1.8 \\
\hline & 13 & ir-1 & 177.4 & 104.5 & 55.2 & 1.7 & 3.2 \\
\hline
\end{tabular}

*Overlying and underlying eolianite formations.
Table 2. Trace Element Concentrations and Ratios for Bulk Filter Samples of Saharan Dust Determined by Emission Spectroscopy

\begin{tabular}{|c|c|c|c|c|c|}
\hline \multirow{2}{*}{$\begin{array}{l}\text { Sample } \\
\text { Number }\end{array}$} & \multicolumn{3}{|c|}{ Concentration, ppm } & \multicolumn{2}{|c|}{ Ratio } \\
\hline & $\mathrm{Zr}$ & $\mathbf{Y}$ & La & $\mathrm{Zr} / \mathrm{Y}$ & $\mathrm{Zr} / \mathrm{La}$ \\
\hline \multicolumn{6}{|c|}{ Sal Island } \\
\hline 1 & 185 & 34 & 51 & 5.4 & 3.6 \\
\hline 2 & 126 & 32 & 56 & 3.9 & 2.3 \\
\hline 3 & 151 & 32 & 51 & 4.7 & 3.0 \\
\hline 4 & 100 & 37 & 51 & 2.7 & 2.0 \\
\hline 5 & 141 & 32 & 58 & 4.4 & 2.4 \\
\hline 6 & 117 & 28 & 48 & 4.2 & 2.4 \\
\hline 7 & 140 & 35 & 51 & 4.0 & 2.7 \\
\hline 8 & 226 & 35 & 54 & 6.5 & 4.2 \\
\hline 9 & 139 & 31 & 58 & 4.5 & 2.4 \\
\hline 10 & 153 & 34 & 54 & 4.5 & 2.8 \\
\hline \multicolumn{6}{|c|}{ Barbados } \\
\hline 11 & 158 & 41 & 64 & 3.9 & 2.5 \\
\hline 12 & 150 & 41 & 63 & 3.7 & 2.4 \\
\hline 13 & 192 & 43 & 70 & 4.5 & 2.7 \\
\hline 14 & 139 & 40 & 67 & 3.5 & 2.1 \\
\hline 15 & 191 & 43 & 69 & 4.4 & 2.8 \\
\hline 16 & 203 & 49 & 70 & 4.1 & 2.9 \\
\hline 17 & 125 & 32 & 57 & 3.9 & 2.2 \\
\hline 18 & 137 & 34 & 58 & 4.0 & 2.4 \\
\hline 19 & 128 & 41 & 41 & 3.1 & 3.1 \\
\hline 20 & 234 & 41 & 67 & 5.7 & 3.5 \\
\hline 21 & 111 & 32 & 64 & 3.5 & 1.7 \\
\hline 22 & 232 & 43 & 84 & 5.4 & 2.8 \\
\hline \multicolumn{6}{|c|}{ Mlami } \\
\hline 23 & 190 & 35 & 48 & 5.4 & 4.0 \\
\hline 24 & 125 & 32 & 48 & 3.9 & 2.6 \\
\hline 25 & 135 & 32 & 58 & 4.2 & 2.3 \\
\hline 26 & 95 & 23 & 51 & 4.1 & 1.9 \\
\hline 27 & 114 & 32 & 51 & 3.6 & 2.2 \\
\hline 28 & 147 & 34 & 51 & 4.3 & 2.9 \\
\hline 29 & 133 & 34 & 69 & 3.9 & 1.9 \\
\hline 30 & 119 & 32 & 56 & 3.7 & 2.1 \\
\hline
\end{tabular}

ing Barbados [Prospero et al., 1970]. Longer travel distances and residence times for African dust reaching Bermuda thus may explain some of the geochemical characteristics of Bermuda's paleosols.

In situ differences in the $\mathrm{Zr} / \mathrm{Y}$ and $\mathrm{Zr} / \mathrm{La}$ ratios also are evident within the profiles of Bermuda's paleosols (Figure 5). At the two sample sites with the best developed profiles (sites 5 and 10), the decrease in the ratios between the $A$ and $B$ horizons exceeds 50\%; the $B$ horizon contains a greater amount of illuviated fine clays. Vertical movement of clays and their accumulation in the B horizon is common in tropical soils. Illuviated material in the Bermuda paleosols permits a clearer resolution of the geochemical signature of the atmospheric dust from which the soils are derived and further justifies limiting the geochemical fingerprinting to $\mathrm{B}$ horizon samples. The low $\mathrm{Zr} / \mathrm{Y}$ and $\mathrm{Zr} / \mathrm{La}$ ratios determined for the $\mathrm{B}$ horizon of Bermuda's paleosols are more consistent with Saharan dust than with the two North American loess source areas.

Given the fact that the calcarenitic sediments comprising the eolianites of Bermuda are cemented as a result of freshwater circulation through the meteoric-vadose and meteoric-phreatic zones [Plummer et al., 1976; Vacher, 1978; Vacher and Wallis, 1992], one might consider the possibility of subsurface sediment transport between stratigraphic units as an explanation 


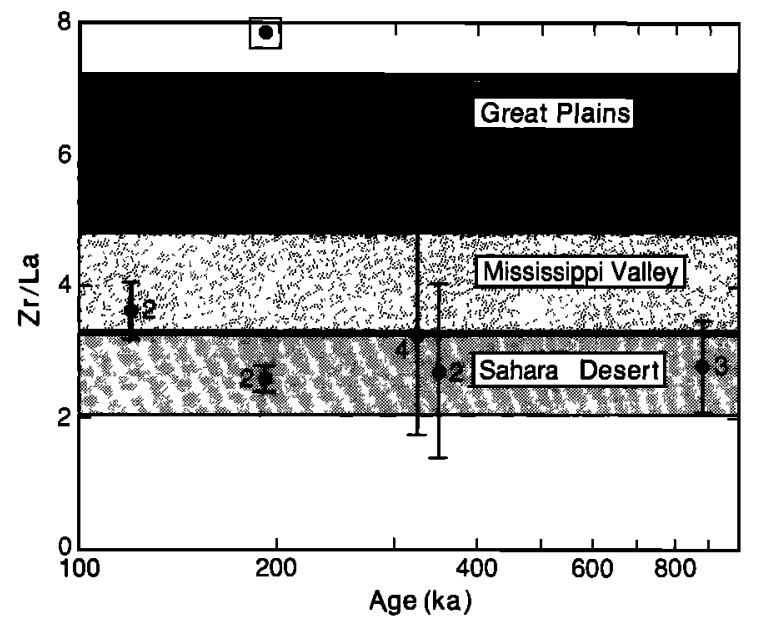

Figure 3. Mean $\mathrm{Zr} / \mathrm{La}$ ratios ( \pm 1 s.d.) from paleosol sample sites as a function of age of underlying eolianite shown in relation to the range of values (mean \pm 1 s.d.) of the three possible source areas: Great Plains, Mississippi Valley, and Sahara Desert. The numbers next to each mean value show the number of paleosol sample sites represented. The boxed-in outlier represents the $\mathrm{Zr} / \mathrm{La}$ ratio from site 14 .

for some of the geochemical variation amongst the paleosol samples. This explanation, however, is of limited significance for the following reasons. First, the six eolianite formations are not stacked in a vertical succession but rather represent a succession of mainly onlapping dune units produced by lateral accretion; as a result, none of the paleosols examined in this study were overlain by younger paleosol units that could have

Table 3. Trace Element Concentrations and Ratios for Size-Fractionated Samples From Barbados of Saharan Dust Determined by Instrumental Neutron Activation Analysis

\begin{tabular}{|c|c|c|c|c|}
\hline \multirow{2}{*}{$\begin{array}{c}\text { Size } \\
\text { Fraction, } \\
\mu \mathrm{m}\end{array}$} & \multirow{2}{*}{$\begin{array}{l}\text { Sample } \\
\text { Number }\end{array}$} & \multicolumn{2}{|c|}{$\begin{array}{c}\text { Concentration, } \\
\text { ppm }\end{array}$} & \multirow{2}{*}{$\begin{array}{l}\mathrm{Zr} / \mathrm{La} \\
\text { Ratio }\end{array}$} \\
\hline & & $\mathrm{Zr}$ & $\mathbf{L a}$ & \\
\hline \multirow[t]{6}{*}{$0-2$} & 27.5 .67 & 152 & 53 & 2.9 \\
\hline & 6.6 .67 & 204 & 60 & 3.4 \\
\hline & 23.8 .67 & 141 & 52 & 2.7 \\
\hline & 26.9.67 & 98 & 44 & 2.2 \\
\hline & 1.10 .68 & 184 & 54 & 3.4 \\
\hline & 6.7 .69 & 161 & 61 & 2.6 \\
\hline \multirow[t]{7}{*}{$2-5$} & 27.5.67 & 183 & 46 & 4.0 \\
\hline & 6.6.67 & 188 & 53 & 3.5 \\
\hline & 3.7 .67 & 202 & 50 & 4.0 \\
\hline & 23.8.67 & 166 & 47 & 3.5 \\
\hline & 26.9.67 & 196 & 45 & 4.4 \\
\hline & 1.10 .68 & 204 & 49 & 4.2 \\
\hline & 6.7 .69 & 249 & 51 & 4.9 \\
\hline \multirow[t]{7}{*}{$5-10$} & 27.5.67 & 225 & 42 & 5.4 \\
\hline & 6.6 .67 & 252 & 40 & 6.3 \\
\hline & 3.7 .67 & 290 & 41 & 7.1 \\
\hline & 23.8.67 & 232 & 42 & 5.5 \\
\hline & 26.9.67 & 269 & 43 & 6.3 \\
\hline & 1.10 .68 & 334 & 44 & 7.6 \\
\hline & 6.7 .69 & 257 & 41 & 6.3 \\
\hline \multirow[t]{5}{*}{$10-20$} & 27.5 .67 & 311 & 33 & 9.4 \\
\hline & 6.6.67 & 459 & 41 & 11.2 \\
\hline & 3.7 .67 & 319 & 41 & 7.8 \\
\hline & 23.8.67 & 327 & 39 & 8.4 \\
\hline & 6.7 .69 & 412 & 41 & 10.0 \\
\hline
\end{tabular}

been a source of contamination. Second, the soil-eolianite contacts on Bermuda are zones of enhanced carbonate diagenesis characterized by well-cemented layers of fine-grained calcite ranging in thickness from 1 to $3 \mathrm{~cm}$ [Plummer et al., 1976]; the extremely low permeability of these calcite layers limits the downward dispersion of particulates by percolating meteoric water. The more likely avenue of particle transport to lower levels would be along irregular fracture planes and solution pipes, which are also lined by calcite walls [Herwitz, 1993]. With the exception of the solution pipe site at Whalebone Bay, none of the paleosol samples were collected from sections of paleosol units where there was evidence of these flow paths in the overlying eolianite.

One of the remaining issues that has not been completely resolved is the possible influence of volcanic detritus derived from the Bermuda platform on the geochemistry of Bermuda's paleosols [Blackburn and Taylor, 1969, 1970; Bricker and Mackenzie, 1970].

\section{Possible Contributions From the Volcanic Platform}

The immobile elements $\mathrm{Ti}$ and $\mathrm{Nb}$ did not yield ratios that could be used to distinguish between the three hypothesized source areas. The ratios involving $\mathrm{Ti}$ and $\mathrm{Nb}$ also were too variable among the Bermuda paleosols to provide a consistent geochemical signature. However, the concentrations of $\mathrm{Ti}, \mathrm{Nb}$, and La did reveal that the paleosol at site 3 (Plate 2f) is more similar to the solution pipe soils at Whalebone Bay (WB) than to the other paleosols (Figure 6). The site 3 paleosol appears to have been influenced by volcanic detritus from the older carbonate formations ( $>300 \mathrm{ka}$ ) on the west side of Castle Harbour in the northeastern section of the Bermuda platform (Figure 1). Seismic surveys have reported volcanic rock at depths of only $30.5 \mathrm{~m}$ below sea level on the rim of Castle Harbour [Gees and Medioli, 1970].

The Upper Town Hill marine facies $\left(Q_{t m}\right)$ at Whalebone Bay is noted for dark bands [Woolard and Ewing, 1939] con-

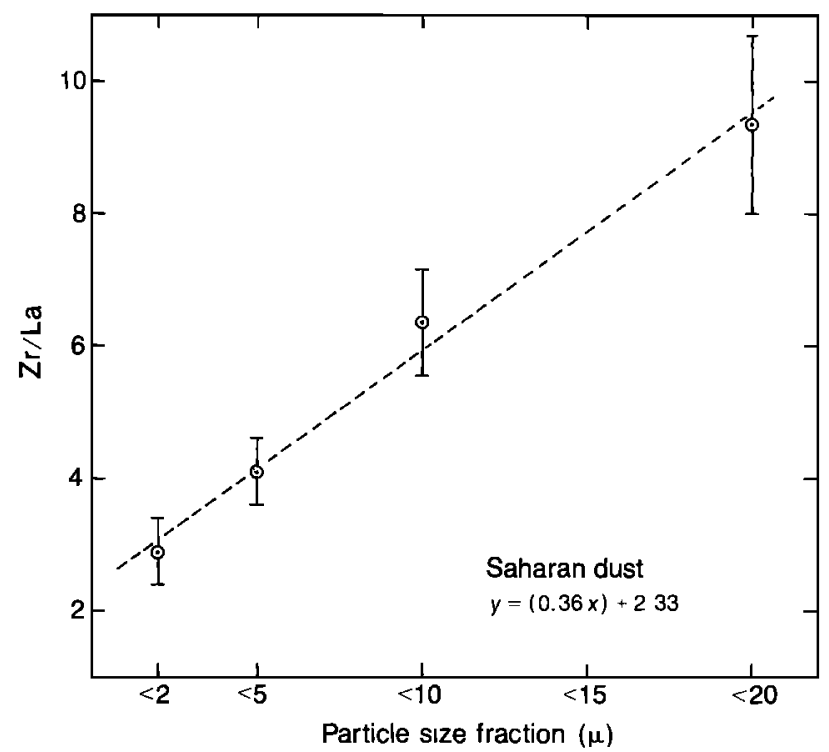

Figure 4. $\mathrm{Zr} / \mathrm{La}$ ratios in Saharan dust as a function of particle size. The best fit relationship has an $r^{2}$ value of $0.99(P<$ 0.001 ). Analyses were performed on samples collected by $J$. Prospero at the aerosolic dust collection site on Barbados [Delany et al., 1967]. 


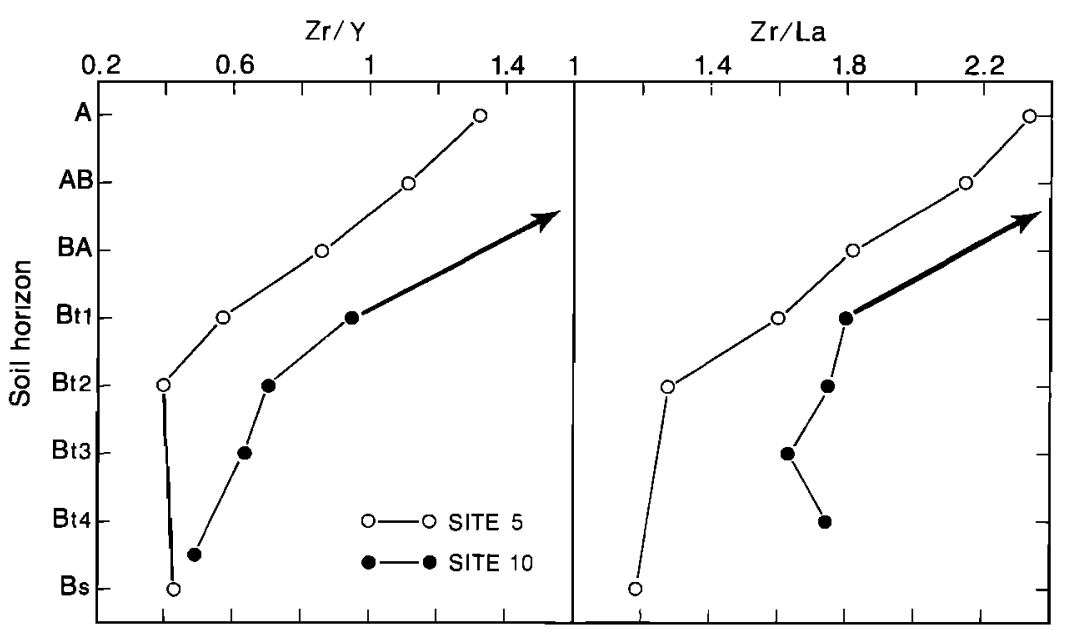

Figure 5. $\mathrm{Zr} / \mathrm{Y}$ and $\mathrm{Zr} / \mathrm{La}$ ratios as function of soil horizon for two selected sites: site 5 and site 10 . The arrows refer to the much larger values in the $\mathrm{A}$ horizon at site 10 (2.7 for $\mathrm{Zr} / \mathrm{Y}$ and 4.4 for $\mathrm{Zr} / \mathrm{La}$ ).

sisting of rounded, vesicular volcanic sand and some obsidian grains cemented in the carbonate matrix (Plate 4a). Band thickness ranges from 0.2 to $1.5 \mathrm{~cm}$ at elevations between 1 and $1.3 \mathrm{~m}$ above mean sea level. Loose black sand derived from these dark bands by chemical weathering and wave abrasion can be found in the swash zone of the present-day shoreline immediately beneath the erosional face of the unit $\mathrm{Q}_{\mathrm{tm}}$ outcrop. Shallow cores of the modern beach reveal bands of sorted volcanic particulates similar to those in the marine facies. The black sand in unit $Q_{1 m}$ thus marks the tıme when the Castle Harbour volcanic rım (a section of the Bermuda platform) was subaerially exposed and the Town Hill eolianites were deposited [Hearty et al., 1992]; the volcanic platform was never again exposed [Land et al., 1967].

Using X ray diffractometry, Blackburn and Taylor [1969] reported that both the Whalebone Bay volcanic sand and nearby surface soils contain varying amounts of apatite, chromite, garnet, gold, goethite, perovskite, anatase, sphene, calcite, magnetite, and volcanic glass. These results led them to suggest that Bermuda's paleosols were derived from volcanic detritus from the Bermuda platform. Bricker and Mackenzie [1970] countered with the argument that the widespread oc-

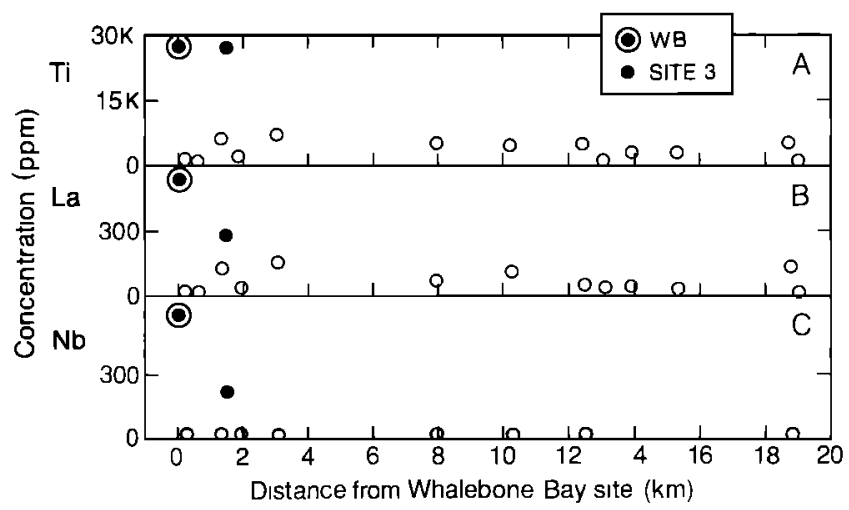

Figure 6. $\mathrm{Ti}, \mathrm{La}$, and $\mathrm{Nb}$ concentrations as a function of distance from Whalebone Bay (WB), the source of volcanic sediment. No significant statistical correlation with distance was found. Only site 3 is consistently sımilar to WB. currence of red clayey soils throughout Bermuda is inconsistent with the soils originating from locally weathered volcanic materials. This interpretation is further supported by the exceptionally high $\mathrm{Ti}, \mathrm{La}$, and $\mathrm{Nb}$ concentrations in the Whalebone Bay solution pipe soils located near the black sand deposits. Only one paleosol unit has comparable concentrations and that is the paleosol between the Upper Town Hill $\left(\mathrm{Q}_{\mathrm{tu}}\right)$ and Walsingham $\left(Q_{w}\right)$ Formations at Site 3 (Plates $2 f$ and $4 b$ ). Other paleosols in the same immediate area (sites 1, 4, and 14) do not have the same geochemical signal. There is no significant relationship between immobile element concentrations and distance from the Whalebone Bay exposure (Figure 6).

Volcanic detritus thus appears to have had a significant effect only on the site 3 geochemical signature rather than on all the soils throughout Bermuda. The $\mathrm{Ti}, \mathrm{La}$, and $\mathrm{Nb}$ concentrations at site 2 are slightly higher than the overall average, but this signal is entirely lacking at site 1 , which also is located on St. George's Island near sites 2 and 3. The higher specific gravity of the volcanic sediment compared with the calcareous biogenic sediments limits their eolian transport and explains why they were not found in any eolianite formation $>5 \mathrm{~m}$ above sea level or in any eolianite formation west of Harrington Sound. During Upper Town Hill time, a major coastal storm overwash event would be a likely cause of volcanic sediment transport from Whalebone Bay to nearby inland locations such as site 3. Subsequent burial of the Whalebone Bay $\mathrm{Q}_{\mathrm{tm}}$ marine facies by eolianites would explain the limited spatial distribution of volcanic detritus in the younger carbonate formations and paleosols. It is clear that volcanic sediment from the Bermuda platform is not the primary or even the secondary parent material of Bermuda's paleosols.

\section{Discussion}

The geochemical signatures of Bermuda's paleosols are most consistent with an influx of Saharan dust mainly in the $<2-\mu \mathrm{m}$ particle size range. This finding is in agreement with the view that aerosolic dust having a mean particle size of $\sim 2$ $\mu \mathrm{m}$ is kept aloft by the trade wind inversion layer [Carlson and Prospero, 1972] and transported long distances across the Atlantic Ocean [Prospero et al., 1970, 1979; Prospero and Carlson, 

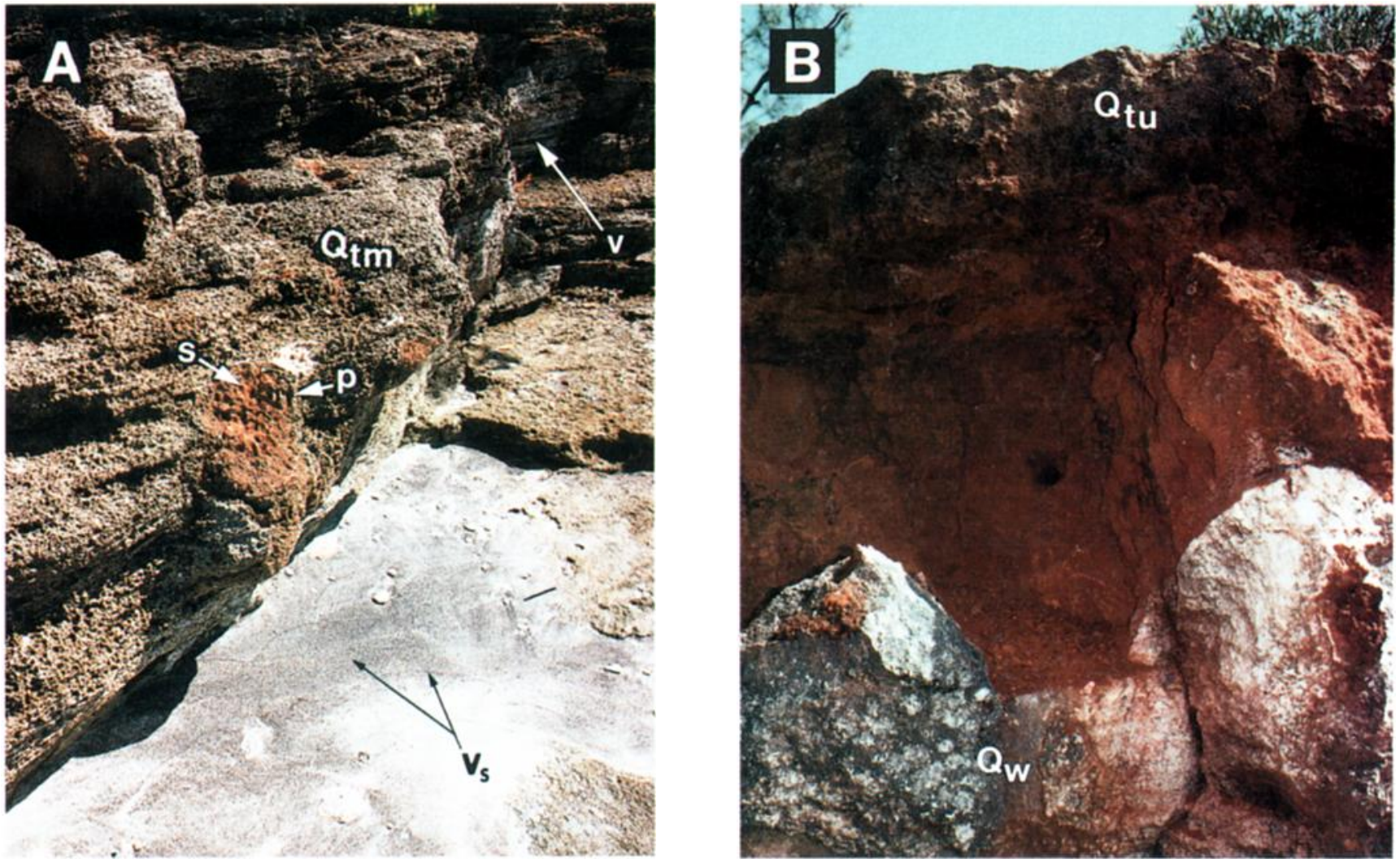

Plate 4. (a) Volcanic black sand $\left(\mathrm{v}_{\mathrm{s}}\right)$ in the intertidal swash zone at Whalebone Bay (WB) derived from band of cemented volcanic sand $(v)$ in the Upper Town Hill marine facies $\left(Q_{t m}\right)$; geochemical analyses were performed on samples from the interiors of soil-filled (s) solution pipes (p). (b) Close-up view of the Shore Hills paleosol at site 3 , located $1.5 \mathrm{~km}$ from Whalebone Bay and the only paleosol unit clearly affected geochemically by volcanic sediment.

1972]. According to Rahn et al. [1979], smaller average particle sizes are associated with longer travel distances. Larger particles unaffected by the inversion layer are deposited mainly within $1000 \mathrm{~km}$ of the west coast of Africa [Schütz, 1979; Jaenicke, 1979; Grousset et al., 1989]. Northwest Africa thus appears to have been the dominant Quaternary source area for Bermuda's paleosols, as was originally suggested by Bricker and Prospero [1969].

Evidence for long-distance transport of Saharan dust beyond the Caribbean was first provided by Syers et al. [1969] working in North Carolina. The oxygen isotope composition of quartz grains in soils was used as a natural tracer for tracking atmospheric dust contributions to Quaternary soils in nonglaciated regions. They found that metamorphic quartz grains common in the lower part of red soil profiles are a product of in situ saprolite weathering of graywacke. But in the upper part of the same soil profiles, the oxygen isotope composition of the quartz fraction resembles that of the red soils of Barbados and the Bahamas rather than the locally derived metamorphic quartz. Syers et al. [1969] suggested that aerosolic dust originating from the Sahara desert was carried into the CaribbeanGulf of Mexico region by the trade winds, then northward in the rising, warm, moist air masses along the eastern seaboard. They further suggested that precipitation was the mechanism by which the aerosolic dust was washed from the atmosphere and deposited on the southern coastal plain.

The red soils of the southeastern United States are similar to Bermudan paleosols in terms of color and texture. The eastern seaboard, however, would not be a likely source area for aerosolic dust because of its moist climatic regime and forest cover throughout the Quaternary. However, if Saharan dust can travel this far north of the Caribbean, then a path from northwest Africa to the Caribbean that then shifts northeast to Bermuda at $32^{\circ} \mathrm{N}$ latitude is certainly a possibility. Atmospheric transport of Asian dust to Alaska over distances exceeding $6000 \mathrm{~km}$ has been documented [Rahn et al., 1979]. Bermuda is only half this distance from northwest Africa.

The most extensive long-term field records of present-day African dust transport are measurements made on Barbados since 1965 [Delany et al., 1967; Prospero and Nees, 1986]. Summer is the season of maximum dust deposition on Barbados, with the trade wind regime providing an extremely efficient transport system for Saharan dust. In Miami, Florida, dust concentrations follow the same seasonal cycle as on Barbados [Prospero et al., 1987], although mean concentrations are typically only a third to a half of those on Barbados [Prospero, 1995].

Arimoto et al. [1995] measured rates of Al, aluminum deposition at a coastal site on the west end of Bermuda over a 2-year period (1989-1991), but only during onshore wind conditions that precluded contamination from local island sources. After converting their $\mathrm{Al}$ measurements to equivalent amounts of mineral dust by assuming the average concentration of $\mathrm{Al}$ in crustal materials, they report a pronounced seasonal cycle of dust concentrations on Bermuda similar to that measured on Barbados: a maximum during summer and a minimum during 
winter. The summer dust events on Bermuda are attributed to air mass trajectories consistent with the strong circulation around the Bermuda-Azores high-pressure center. Mean mineral dust concentrations on Bermuda, however, are less than those on Barbados [Prospero, 1996].

Some dust transport events associated with sources in North America have been detected on Bermuda [Chen and Duce, 1983], but the dust concentrations associated with these events are much lower than those for African dust events [Prospero, 1996]. Arimoto et al. [1995] grouped Bermudan aerosol samples according to air mass trajectory and found that the mean Al concentration for trajectories from the east is approximately 10 times greater than that for trajectories from North America.

When considering these findings in relation to the origin of Bermudan paleosols, the challenge is ascertaining the extent to which the present-day interglacial is representative of Quaternary dust deposition over the period 880 to $85 \mathrm{ka}$. Given the effects of agriculture and poor land use practices on soil dust deflation [Prospero, 1996], one must first recognize the possibility that present-day patterns of dust transport may not be representative of past glacials and interglacials. However, the paleosol geochemistry reported in this paper suggests that the current atmospheric circulation pattern in the North Atlantic has persisted and may have been even more pronounced than it is at present.

\section{Conclusion}

Saharan aerosolic dust has contributed significant amounts of silicates and other minerals not only to the red soils of the Caribbean and the eastern seaboard of North America but also to the red soils of Bermuda. Our study highlights the importance of particle size in the identification of geochemical signatures using immobile element ratios. Volcanic detritus from the Bermuda platform has had no detectable influence on Bermudan paleosols, except at one location. Aerosolic dust originating from the American-Canadian continental landmasses and carried by the jet stream westerlies may have contributed, but this contribution cannot be clearly detected in Bermuda's paleosols. This interpretation is a slight departure from our original study, based on Bermuda soil material collected from subaerially exposed solution pipes, in which we suggested the possibility of mixing of aerosolic dust from both the Sahara and an unknown North American source area [Herwitz and Muhs, 1995].

Changes in accumulation rates of eolian dust in deep-sea cores [Rea, 1994] from the eastern Atlantic near Africa indicate that wind systems were more vigorous and Saharan dust transport was significantly greater during glacial maxima than during interglacials [Bowles, 1975; Kolla et al., 1979; Pokras and Mix, 1985; Grousset et al., 1989; Francois and Bacon, 1991; Rea, 1994]. More recently, Yung et al. [1996] concluded that the increased dust concentrations found in polar ice cores from the last glacial maximum are the result of stronger winds and a weakened hydrologic cycle as diagnosed by reduced rates of wet deposition and longer washout lifetimes of aerosolic dust particles. If Bermuda's red clay soils formed most rapidly during glacial maxima, then the Saharan signature would be in agreement with Kutzbach's [1987] general circulation model. His model indicates that during glacial maxima the northeast summer trade winds reached latitudes higher than $30^{\circ} \mathrm{N}$ and were stronger than at present. The dominance of Saharan dust in Bermudan paleosols thus indicates that sea surface temper- atures in the North Atlantic during glacial summers [Keffer et al., 1988] may not have been low enough to displace the Gulf Stream and Bermuda's subtropical atmospheric circulation pattern south of $32^{\circ} \mathrm{N}$.

Acknowledgments. We thank David Lines, Rip Heminway, Stephen Kerns, Joel Frisch, Isaac Phillips, Denise Lajoie, Samantha Kaplan, Robert Redpath, Michael McGeehan, Patrick Burns, Sonya Sundaram, and Adam Sadowsky for their assistance with the sample collection. Thanks also to Marith Reheis and Ralph Shroba for their many constructive comments on an earlier draft of this paper. This study was funded by a grant from the National Geographic Society Committee for Research and Exploration.

\section{References}

Arimoto, R., R. A. Duce, B. J. Ray, W. G. Ellis Jr., J. D. Cullen, and J. T. Merrill, Trace elements in the atmosphere over the North Atlantic, J. Geophys. Res., 100, 1199-1214, 1995.

Blackburn, G., and R. M. Taylor, Limestone and red soils of Bermuda, Geol. Soc. Am. Bull., 80, 1595-1598, 1969.

Blackburn, G., and R. M. Taylor, Limestone and red soils of Bermuda: Reply, Geol. Soc. Am. Bull., 81, 2525-2526, 1970.

Bowles, F. A., Paleoclimatic significance of quartz/illite variations in cores from eastern equatorial North Atlantic, Quat Res., 5, 225-235, 1975.

Bretz, H., Bermuda: A partially drowned, late mature, Pleistocene karst, Geol. Soc. Am. Bull. 71, 1729-1754, 1960.

Bricker, O., and F. T. Mackenzie, Limestones and red soils of Bermuda: Discussion, Geol. Soc. Am. Bull., 81, 2523-2524, 1970.

Bricker, O., and J. M. Prospero, Aurborne dust on the Bermuda Islands and Barbados, Eos Trans $A G U, 50,176,1969$.

Carlson, T. N., and J. M. Prospero, The large-scale movement of Saharan air outbreaks over the equatorial North Atlantic, J. Appl. Metcorol., 11, 283-297, 1972.

Chapman, S. L., and M. E. Horn, Parent material uniformity and origin of silty soils in northwest Arkansas based on zirconumtıtanium contents, Soll Scl. Soc. Am. Proc., 32, 265-271, 1968.

Chen, L., and R. A. Duce, The sources of sulfate, vanadium and mineral matter in aerosol particles over Bermuda, Atmos Environ., 17, 2055-2064, 1983.

Delany, A. C., D. W. Parkin, J. J. Griffin, E. D. Goldberg, and B. E. F. Reimann, Airborne dust collected at Barbados, Geochim. Cosmochim. Acta, 31, 885-909, 1967.

Fisk, H. N., Loess and Quaternary geology of the lower Mississippi Valley, J. Geol., 59, 333-356, 1951.

Francois, R., and M. P. Bacon, Varrations in terrigenous input into the deep equatorial Atlantic during the past 24,000 years, Science, 251, 1473-1476, 1991.

Gees, R. A., and F. Mediolı, A continuous sessmic survey of the Bermuda platform, I, Castle Harbour, Mant. Sediments, 6, 21-25, 1970.

Grousset, F., P. Buat-Menard, D. Boust, R. Tian, S. Baudel, C. Pujol, and C. Vergnaud-Grazzini, Temporal changes of aeolian Saharan input in the Cape Verde abyssal plain since the last glacial period, Oceanol. Acta, 11, 177-185, 1989.

Harmon, R. S., L. S. Land, R. M. Mitterer, P. Garrett, H. P. Schwarcz, and G. J. Larson, Bermuda sea level during the last interglacial, Nature, 289, 481-483, 1981.

Harmon, R. S., R. M. Mitterer, N. Kriausakul, L. S. Land, H. P. Schwarcz, P. Garrett, G. J. Larson, H. L. Vacher, and M. Rowe, Uranium-series and amino-acid racemization geochronology of Bermuda: Implications for eustatic sea-level fluctuations over the past 250,000 years, Palaeogeogr. Palaeoclimatol. Palaeoecol., 44, 41-70, 1983.

Hearty, P. J., and H. L. Vacher, Quaternary stratigraphy of Bermuda: A high-resolution pre-Sangamonian rock record, Quat. Sct. Rev., 13, 685-697, 1994.

Hearty, P. J., H. L. Vacher, and R. M. Mitterer, Aminostratigraphy and ages of Pleistocene limestones of Bermuda, Geol. Soc Am. Bull., 104, 471-480, 1992.

Herwitz, S. R., Stemflow influences on the formation of solution pipes in Bermuda eolianite, Geomorphology, 6, 253-271, 1993.

Herwitz, S. R., and D. R. Muhs, Bermuda solution pipe soils: A 
geochemical evaluation of eolian parent materials, in Terrestrial and Shallow Marine Geology of the Bahamas and Bermuda, edited by $\mathrm{H}$ A. Curran and B. White, Spec. Pap. Geol. Soc. Am., 300, 311-323, 1995.

Holliday, V. T., The geologic record of wind erosion, eolian deposition, and aridity on the Southern High Plains, Great Plains Res., 1, $6-25,1991$.

Hooghiemstra, H., Palynological records from northwest Africa marine sediments: A general outline of the interpretation of the pollen signal, Philos. Trans. R. Soc. London, Sec. B, 318, 431-449, 1988.

Hooghiemstra, H., A. Bechler, and H.-J. Beug, Isopollen maps for 18,000 years B.P. of the Atlantic offshore of northwest Africa: Evidence for paleowind circulation, Paleoceanography, 2, 561-582, 1987.

Jaenicke, R., Monitoring and critical review of the estimated source strength of mineral dust from the Sabara, in Saharan Dust: Mobilization, Transport, Deposition, edited by C. Morales, pp. 233-242, John Wiley, New York, 1979.

Johnson, R. G., and B. King, Energy-dispersive x-ray fluorescence spectrometry, in Methods for Geochemical Analysis, edited by P. A. Baedecker, U.S. Geol. Surv. Bull., 1770, F1-F5, 1987.

Keffer, T., D. G. Martinson, and B. H. Corliss, The position of the Gulf Stream during Quaternary glaciations, Science, 241, 440-442, 1988.

Kolla, V., P. E. Biscaye, and A. F. Hanley, Distribution of quartz in late Quaternary Atlantic sediments in relation to climate, Quat. Res., 11, 261-277, 1979.

Kutzbach, J. E., The influence of changing orbital parameters and surface boundary conditions on climate simulations for the past 18000 years, J. Atmos. Sci., 43, 1726-1759, 1987.

Land, L. S., F. T. Mackenzie, and S. J. Gould, Pleistocene history of Bermuda, Geol. Soc. Am. Bull., 78, 993-1006, 1967.

Livingston, W., Observations on the structure of Bermuda, Geogr. J., 104, 40-48, 1944.

McCauley, J. F., C. S. Breed, M. J. Grolier, and D. J. Mackinnon, The U.S. dust storm of February 1977, Spec. Pap. Geol. Soc. Am., 186, $123-147,1981$.

Moresi, M., and G. Mongelli, The relationship between terra rossa and the carbonate-free residue of the underlying limestones and dolostones in Apulia, Italy, Clays Clay Miner., 23, 439-446, 1988.

Muhs, D. R., C. A. Bush, K. C. Stewart, T. R. Rowland, and R. C. Crittenden, Geochemical evidence for Saharan dust parent materials for soils developed on Quaternary limestones of Caribbean and western Atlantic islands, Quat. Res., 33, 157-177, 1990.

Officer, C. B., M. Ewing, and P. C. Wuenschel, Seismic refraction measurements in the Atlantic Ocean, IV, Bermuda, Bermuda Rise, and Nares Basin, Geol. Soc. Am. Bull., 63, 777-808, 1952.

Pirsson, L. V., Geology of Bermuda Island: The igneous platform, Am. J. Sci., 38, 189-206, 331-344, 1914.

Plummer, L. N., H. L. Vacher, F. T. Mackenzie, O. P. Bricker, and L. S. Land, Hydrochemistry of Bermuda: A case history of groundwater diagenesis of biocalcarenites, Geol. Soc. Am. Bull., 87, 1301$1316,1976$.

Pokras, E. M., and A. C. Mix, Eolian evidence for spatial variability of late Quaternary climates in tropical Africa, Quat. Res., 24, 137-149, 1985.

Prasad, G., On the origin of red clays on Quaternary limestone along the East African coast, Z. Geomorph. Suppl., 48, 51-64, 1983.

Prospero, J. M., Atmospheric dust studies on Barbados, Bull. Am. Meteorol. Soc., 49, 645-652, 1968.

Prospero, J. M., The atmospheric transport of particles to the ocean, in Particle Flux in the Ocean, edited by V. Ittekkot, P. Schäfer, S. Honjo, and P. J. Depetris, pp. 19-52, John Wiley, New York, 1996.

Prospero, J. M., and T. N. Carlson, Vertical and areal distribution of Saharan dust over the western equatorial North Atlantic Ocean, $J$. Geophys. Res., 77, 5255-5265, 1972.

Prospero, J. M., and R. T. Nees, Impact of North African drought and El Niño on mineral dust in the Barbados trade wind, Nature, 320, 735-738, 1986.

Prospero, J. M., E. Bonatti, C. Schubert, and T. N. Carlson, Dust in the Caribbean atmosphere traced to an African dust storm, Earth Planet. Sci. Lett., 9, 287-293, 1970.

Prospero, J. M., D. L. Savoie, T. N. Carlson, and R. T. Nees, Monitoring Saharan aerosol transport by means of atmospheric turbidity measurements, in Saharan Dust: Mobilization, Transport, Deposition, edited by C. Morales, pp. 171-186, John Wiley, New York, 1979.
Prospero, J. M., R. T. Nees, and M. Uematsu, Deposition rate of particulate and dissolved aluminum derived from Saharan dust in precipitation at Miami, Florida, J. Geophys. Res., 92, 14,723-14,731, 1987.

Pye, K., Red beds, in Chemical Sediments and Geomorphology: Precipttates and Residua in the Near-Surface Environment, edited by A. S. Goudie and K. Pye, pp. 227-263, Academic, San Diego, Calif., 1983.

Pye, K., Aeolian dust transport and deposition over Crete and adjacent parts of the Mediterranean Sea, Earth Surf. Processes Landforms, 17, 271-288, 1992

Pye, K., and R. Johnson, Stratigraphy, geochemistry, and thermoluminescence ages of lower Mississippi Valley loess, Earth Surf. Processes Landforms, 13, 103-124, 1988.

Rahn, K. A., R. D. Borys, G. E. Shaw, L. Schütz, and R. Jaenicke, Long-range impact of desert aerosol on atmospheric chemistry: Two examples, in Saharan Dust: Mobilization, Transport, Deposition, edited by C. Morales, pp. 243-266, John Wiley, New York, 1979.

Rea, D. K., The paleoclimatic record provided by eolian deposition in the deep sea-The geologic history of wind, Rev. Geophys., 32, 159-195, 1994

Rowe, M. P., An Explanation of the Geology of Bermuda, Min. of Works and Eng., Hamilton, Bermuda, 1990.

Ruhe, R. V., J. G. Cady, and R. S. Gomez, Paleosols of Bermuda, Geol. Soc. Am. Bull., 72, 1121-1142, 1961.

Sayles, R. W., Bermuda during the ice age, Proc. Am. Acad. Arts Sci., 66, 380-467, 1931

Schutz, L., Sahara dust transport over the North Atlantic OceanModel calculations and measurements, in Saharan Dust: Mobilization, Transport, Deposition, edited by C. Morales, pp. 267-278, John Wiley, New York, 1979.

Stanley, D. J., and D. J. P. Swift, Bermuda's southern aeolianite reef tract, Science, 157, 677-681, 1967.

Syers, J. K., M. L. Jackson, V. E. Berkheiser, R. N. Clayton, and R. W. Rex, Eolian sediment influence on pedogenesis during the Quaternary, Soil Sci., 107, 421-427, 1969.

Vacher, H. L., Coastal dunes of younger Bermuda, in Coastal Geomorphology, edited by D. R. Coates, pp. 355-391, Publ. in Geomorphol., State Univ. of N. Y., Binghamton, 1973.

Vacher, H. L., Hydrogeology of Bermuda-Significance of an acrossthe-island variation in permeability, J. Hydrol., 39, 207-226, 1978.

Vacher, H. L., and P. J. Hearty, History of stage 5 sea level in Bermuda: Review with new evidence of a brief rise to present sea level during substage 5A, Quat. Sci. Rev., 8, 159-168, 1989.

Vacher, H. L., and T. N. Wallis, Comparative hydrogeology of freshwater lenses of Bermuda and Great Exuma Island, Bahamas, Ground Water, 30, 15-20, 1992.

Vacher, H. L., M. P. Rowe, and P. Garrett, The Geological Map of Bermuda, 1:25,000 scale. Public Works Dep., Hamilton, Bermuda, 1989.

Vacher, H. L., P. J. Hearty, and M. P. Rowe, Stratigraphy of Bermuda: Nomenclature, concepts, and status of multiple systems of classification, in Terrestrial and Shallow Marine Geology of the Bahamas and Bermuda, edited by H. A. Curran and B. White, Spec. Pap. Geol. Soc. Am., 300, 271-294, 1995.

Windom, H. L., and C. F. Chamberlain, Dust-storm transport of sediments to the North Atlantic Ocean, J. Sediment. Petrol., 48, 385-388, 1978

Woolard, G. P., and M. Ewing, Structural geology of the Bermuda Islands, Nature, 143, 898, 1939.

Yung, Y. L., T. Lee, C.-H. Wang, and Y.-T. Shieh, Dust: A diagnostic of the hydrologic cycle during the last glacial maximum, Science, 271, 962-963, 1996.

S. R. Herwitz, Departments of Geography and Biology, Clark University, Worcester, MA 01610. (e-mail: sherwitz@vax.clarku.edu)

S. Mahan, D. R. Muhs, and B. Vaughn, U.S. Geological Survey, MS 974, Box 25046, Denver Federal Center, Denver, CO 80255.

J. M. Prospero, Rosenstiel School of Marine and Atmospheric Sciences, University of Miami, 4600 Rickenbacker Causeway, Miami, FL 33149 .

(Received March 20, 1996; revised July 12, 1996; accepted July 12, 1996.) 